\title{
Vatandaşların Yerel Hizmetlere Yönelik Memnuniyet Algıları Üzerine Bir Araştırma: Kars Belediyesi Örneği
}

DOI: $10.26466 /$ opus.676976

\section{Onur Akçakaya* -Zeynep Ceylin Ecer **}

* Dr. Öğr. Üyesi, Ardahan Üniversitesi/İktisadi ve İdari Bilimler Fakültesi, Ardahan/Türkiye
E-Posta: onurakcakaya@ardahan.edu.tr
ORCID: 0000-0002-7328-5380

** Y. L. Öğrencisi, Ardahan Üniversitesi/İktisadi ve İdari Bilimler Fakültesi, Ardahan/Türkiye

E-Posta: celogluzeynepceylin@gmail.com

ORCID: 0000-0002-6914-0402

\section{Öz}

Neo-liberalizm etkisiyle ortaya çıkan piyasa temelli kamu yönetimi anlayışları son zamanlarda etkisini iyiden iyiye artırmıştır. Günümüzde vatandaşlar, artık müşteri olarak algılanmakta; kamu hizmetlerinde hız, kalite ve etkinlik ön plana çıkmaktadır. Bununla birlikte, kamu yönetimindeki yeni anlayıslar yerel yönetimleri de yakından ilgilendirmektedir. Zira yerel seçimlerin kazanılması hizmetlerin etkin, kaliteli ve hızlı bir şekilde yürütülmesine bağhldır. Bu çerçevede, 'yerel ölçekte sunulan hizmetlerden memnuniyet düzeyinin belirlenmesi' büyük önem arz etmektedir. Bu çalışmanın amacl, Kars Belediyesi örneğinde, vatandaşlarn belediyecilik hizmetlerinden memnuniyet düzeylerinin belirlenmesidir. Çalışmada yüz yüze görüşme tekniği ile kantitatif araştırma yöntemi kullanılmıştır. Bu çerçevede katılımcılara toplam 550 anket dağıtılmış; ancak sorulara titizlikle yanıt veren katılımcıların anketleri değerlendirmeye alınmıştır. Anketlerden elde edilen veriler SPSS 12.0 paket programı kullanılarak analiz edilmiş ve yorumlanmıştır. Araştırmadan elde edilen bulgulardan bazılarına göre, Kars ilinin katılımcilar tarafindan en önemli görülen yerel sorunlarl, cadde ve sokakların istenilen düzeyde temiz olmaması, yol yapım ve bakım hizmetlerinin noksanlı̆̆ı ve sosyal imkânların yetersizliğidir. Vatandaşların en fazla memnun olduğu yerel hizmetler, halk sağlığı denetimleri, mezarlı ve itfaiyelambulans hizmetler iken; memnuniyet düzeylerinin en düşük olduğu hizmetler ise; cadde/sokak temizliği, çevre koruma, ă̆açlandırma, otopark hizmetleri ile yol yapım ve bakım hizmetleridir. Bu veri ve bulgulardan hareketle denilebilir ki; vatandaşların memnuniyet düzeyleri ile sorun olarak algıladıkları konu başlıkları arasında bir benzerlik vardır. Nitekim katılımcıların sorun olarak gördükleri cadde ve sokakların istenilen düzeyde temiz olmaması, yol yapım ve bakım hizmetlerinin noksanlğl ve sosyal imkânların yetersizliği gibi konular; ayn zamanda vatandaşların yerel hizmetlerden memnuniyet düzeylerinin en düşük olduğu konu başlıkları arasındadır.

Anahtar Kelimeler: Yerel yönetimler, yerel siyaset, yerel kamu hizmetleri, vatandaş memnuniyeti. 


\title{
A Research on Citizens' Perceptions of Satisfaction for Local Services: The Case of Kars Municipality
}

\begin{abstract}
Market-based public administration approaches that have emerged under the influence of neoliberalism have recently increased their influence. Today, citizens are perceived as customers; and the criteria of efficiency, speed and quality are brought into the forefront in public services. However, new public management approaches concern local governments closely. This is because winning the local elections depends on the efficient, high quality and fast execution of the services. In this context, it is significantly important to determine the level of satisfaction of the citizens from the local services. The aim of this study is to determine the satisfaction levels of citizens from municipal services in the case of Kars Municipality. In this study, face-to-face interview technique and quantitative research method were used. In this framework, a total of 550 questionnaires were distributed to the participants; however, the questionnaires of the participants who meticulously answered the questions were evaluated. The data obtained from the questionnaires were analysed and interpreted using the SPSS 12.0 package program. According to some of the findings obtained from the research, the most important local problems of the city of Kars are the lack of clean streets and streets, lack of road construction and maintenance services and inadequate social facilities. While the local services that citizen are most satisfied with are public health inspections, cemetery and fire / ambulance services; services with the lowest level of satisfaction; street / street cleaning, environmental protection, afforestation, parking services and road construction and maintenance services. Based on these data and findings, it can be said that; there is a similarity between the satisfaction levels of citizens and the topics they perceive as a problem. Thus, what the participants accepted as a problem such as cleaning of the streets, lack of road construction and maintenance services, and insufficient social facilities are also among the topics that citizens have the lowest level of satisfaction with local services.
\end{abstract}

Keywords: Local governments, local politics, local public services, user satisfaction 


\section{Giriş}

Bütün disiplinler gibi kamu yönetimi de sürekli değişim ve dönüşümler geçirmektedir. Uzunca bir dönem geleneksel kuramın etkisinde kalan ortodoks kamu yönetimi, neo liberalist kuramcllar ve post modernist düşünürler tarafından ciddi eleştirilere maruz bırakılmıştır. Bu eleştiriler kamu bürokrasisindeki hantallık, aşırı merkeziyetçilik, devlet fonksiyonlarındaki aşırı büyüme ve kamu hizmetlerindeki etkinsizlik ve verimsizlik gibi alanlarda yoğunlaşmıştır. Geleneksel teoriye yönelik eleştirel yaklaşımlar, kamu yönetiminde yeni ve disiplinler arası yaklaşımlara yönelik arayışları beraberinde getirmiştir. 1980'li yıllardan günümüze 'Yeni Kamu Yönetimi', 'Yeni Kamu İşletmeciliği', 'Yeni Kamu Hizmeti' ve 'Post-Bürokratik Kamu Yönetimi' gibi isimlerle ortaya çıkan bu yeni yaklaşımlar, dış dünyanın değişimlerine kolayca uyum sağlayan; değişken insan ihtiyaçlarına uygun çözümler üreten; ve kamu hizmetlerinde etkinlik, verimlilik, şeffaflık, hızlılık, hesap verilebilirlik ve kalite gibi unsurları ön plana çıkaran bir kamu yönetimi disiplini ortaya çıkarmayı amaçlamaktadır. Şüphesiz, yeni yaklaşımların etkisi yerel yönetimlerde de hissedilmektedir. Yerel yönetimler vatandaşlara en yakın birimler olarak onların talep ve beklentilerine en iyi cevap verebilen kuruluşlardır. Zira seçimlerle iş başına gelen yerel yöneticiler, meşruiyetlerini vatandaşların seçim dönemlerinde açıkladıkları iradelere borçludur. Bu bağlamda, yerel yöneticilerin seçimleri kazanıp görevlerini sürdürmeleri, kamu hizmetlerinin etkin, verimli, kaliteli ve hızlı bir şekilde sunulmasına bağlıdır.

Öte yandan, literatürde vatandaşların hizmetlerden memnuniyetleri ile sunulan hizmetlerin kalitesi arasında doğrudan bir ilişki bulunduğu kanısı yaygindır (Cronin, Brady ve Hult, 2000, s.193). Yerel hizmetlerin etkin ve verimli bir şekilde sunulmasında etkili bir kontrol süreci büyük önem arz etmektedir. Bu çerçevede, vatandaşların yerel görevlilere ve yerel hizmetlere yönelik memnuniyet düzeylerinin belirlenmesinin bu kontrol sürecini hızlandırdığı düşünülmektedir. Buna rağmen, birçok yerel yönetim kuruluşu vatandaş memnuniyetine yönelik kamuoyu araştırmalarına beklenenden az başvurmaktadır. Bu durum vatandaşların talep ve beklentilerinin tam ve yerinde tespit edilememesine neden olabilmektedir. 
Bu çalışma, 31 Mart 2019 yerel seçimleri öncesinde Kars ilinde ikamet eden ve basit tesadüfi örnekleme yöntemiyle belirlenen vatandaşlara uygulanan anketler aracilığıyla belediye kuruluşuna, personeline ve hizmetlerine yönelik memnuniyet düzeylerini belirlemeyi amaçlayan ampirik bir çalışmadır. Literatürdeki yaygın görüşe göre kamu hizmetlerinin etkin, hızlı ve nitelikli bir şekilde üretilmesi ile vatandaşların bu hizmetlerden duydukları memnuniyet arasında yakın bir ilişki bulunmaktadır. Bu nedenle, veri analizi ve bulguların yorumlanması aşamasına geçmeden önce kamu hizmeti kavramına yönelik gelişmeler, kamu yönetimi disiplinindeki kuramsal değişim ve dönüşümler bağlamında ele alınmaktadır.

\section{Kuramsal Çerçeve}

Kamu hizmeti kavramı hem maddi hem de organik anlamda kullanılan bir kavramdır. Maddi anlamda kamu hizmeti kamu yararını gerçekleştirmeye yönelik bir faaliyeti; organik anlamda kamu hizmeti ise bu faaliyeti gerçekleştiren kamu örgütünü ifade etmektedir. Kurumsal anlamını bir yana bırakırsak bir faaliyet olarak kamu hizmeti, "bir kamu tüzel kişisi tarafindan üstlenilen; doğrudan doğruya o kamu tüzel kişisi ya da onun kontrolünde bir özel kişi tarafından yürütülen kamu yarar amacına yönelik faaliyet" olarak tanımlanabilir (Gözler ve Kaplan, 2012, s.156-157).

Kamu hizmeti durağan bir kavram değildir. Değişen kamu yararı gereklerine ve müşterek ihtiyaçlara bağlı olarak kamu hizmeti de değişmekte ve gelişmektedir (Gözler ve Kaplan, 2012, s.164). Denhardt ve Denhardt (2000, s.552) sadece kamu hizmeti kavramının değil kamu yönetimi disiplininin de başlı başına değişim ve dönüşümler geçirdiğini; bu değişim ve dönüşümlerin ilerici reform retoriğinin ötesinde, uygulama alanına da yansıdığını belirtmektedir. Dolayısıyla kamu hizmeti kavramında ortaya çıkan değişimleri doğru bir şekilde anlayabilmek için kamu yönetimi disiplinindeki reform sürecine bakmak gerekmektedir.

Kamu yönetimindeki değişim ve dönüşümlerin akla gelen ilk muhatabı uzun bir süredir geçerliğini koruyan geleneksel kuram olmuştur. Geleneksel yaklaşım uzun yıllar boyunca kamu sektöründe işleri idare etmenin en iyi yolu olarak görülmüş; en başarıll, tutarlı ve akılcı teori olarak kabul edilmiştir. Teorik arka planı W. Wilson, F. Taylor ve M. Weber'in düşüncelerine ve İngiltere'deki Northcote-Trevelyan Raporu'na dayanan geleneksel 
kuram (Katsamunska, 2012, s.75), kendine özgü temeller üzerine inşa edilmiştir. Kısaca değinmek gerekirse geleneksel teoride örgütsel yapı Weber'in katı, merkeziyetçi, kariyere ve biçimselliğe dayalı ve kuralcı bürokrasi modeline dayanmaktadır. Devlet kamusal mal ve hizmet sunumunu kendi örgütleri vasıtasıyla gerçekleştirmekte; piyasa aktörlerine yetki aktarımı kısitlı seviyede tutulmaktadır. Kamu hizmetlerinin planlanmasında ve yürütülmesinde siyasiler ve bürokratlar arasında görev ayrımı bulunmaktadır. Buna göre siyasiler politika üretmekten, bürokratlar ise bu politikaların uygulanmasından sorumludur. Bürokratlar ayn zamanda siyasiler tarafından denetlenmektedir. Kamu yönetimi ve özel yönetim yapısal ve işlevsel olarak birbirinden ayrılmıştır. Bu ayrım yasalara bağllık, kamu yararı, kamu gücü ayrıcalıkları, tarafsızlık ve eşitlik unsurları çerçevesinde yapılmaktadır (Eryılmaz, 2010, s.16).

Klasik teori üzerinde etkili olan Keynesyen ekonomik politikalar refah devleti olgusunu ortaya çıarmış; refah devleti II. Dünya Savaşı'ndan sonra da etkisini sürdürmüştür (Thorsen, 2009, s.9). Ancak 1980'li yılların başında Birleşik Devletler ve Birleşik Krallık'ta neo-liberal partilerin iktidara gelmesiyle, refah devleti yoğun bir şekilde eleştirilmeye başlanmıştır. Bunun hemen ardından, Yeni Zelanda ve Avustralya'da da neo-liberal görüş etkili olmaya başlamıştır (Gruening, 2001, s.2). Bu dönemde ortaya çıkan yeni kamu yönetimi yaklaşımı kamu yönetimi alanındaki en çarpıcı küresel eğilimlerden birisi olarak değerlendirilmiştir (Hood, 1991, s.3). Yeni kamu yönetimi özelleştirme, desantralizasyon, katılım, stratejik planlama, hesap verebilirlik, performans değerlendirmesi, rekabetçilik, yönetimde esneklik, personel yönetimi, finansal yönetim ve bilgi teknolojileri gibi piyasa temelli pek çok unsuru kamu yönetimi disiplinine entegre etmeyi hedeflemiştir (Gruening, 2001, s.2).

Kamu yönetiminde gerek teoride gerekse de pratikte gerçekleşen gelişmeler, yeni kamu yönetimi yaklaşımı sonrasında da devam etmiştir (Denhardt, 2000, s.552). Denhardt ve Denhardt tarafindan ortaya atılan 'Yeni Kamu Hizmeti Yaklaşımı' yeni kamu yönetimi anlayışına eleştiriler getirmiş; demokratik vatandaşlık, toplum modelleri ve sivil toplum, kurumsal hümanizm ve post modern kamu yönetimi gibi unsurlara vurgu yapmıştır (2007, s.27). Bu bağlamda, yeni kamu hizmeti yaklaşımının disipline farklı bir boyut kazandırdığı söylenebilir. 
Geleneksel kuram, Yeni Kamu Yönetimi ve Yeni Kamu Hizmeti yaklaşımları arasında kuramsal temeller, örgütsel yapı, kamu hizmeti anlayışı, temel politikalar ve uygulamalar gibi temel belirleyiciler çerçevesinde kapsamlı bir mukayese yapılması kamu yönetimindeki değişim ve dönüşümlerin anlaşılmasında önem arz etmektedir.

Tablo 1'de her üç yaklaşım arasında temel belirleyiciler çerçevesinde karşılaştırmalar yapılmaktadır (Denhardt ve Denhardt, 2007, s.29):

Tablo 1. Geleneksel Kuram, Yeni Kamu Yönetimi ve Yeni Kamu Hizmeti Yaklaşımlarının Karşılaştırılması

\begin{tabular}{|c|c|c|c|}
\hline & Geleneksel Kuram & Yeni Kamu Yönetimi & Yeni Kamu Hizmeti \\
\hline $\begin{array}{l}\text { Teorik/Epistemolojik } \\
\text { Temeller }\end{array}$ & $\begin{array}{l}\text { Politik teori, sosyal } \\
\text { ve politik yorum }\end{array}$ & $\begin{array}{l}\text { Ekonomik teori, daha } \\
\text { gelişmiş diyalog }\end{array}$ & $\begin{array}{l}\text { Demokratik teori, } \\
\text { bilgiye yorumlayıcı/eleştirel } \\
\text { yaklaşım }\end{array}$ \\
\hline $\begin{array}{l}\text { Hâkim Rasyonellik/ } \\
\text { Davranış Modelleri }\end{array}$ & $\begin{array}{l}\text { Sinoptik Rasyonel- } \\
\text { lik/İdari }\end{array}$ & $\begin{array}{l}\text { Teknik ve Ekonomik } \\
\text { Rasyonellik/Ekonomik } \\
\text { İnsan }\end{array}$ & $\begin{array}{l}\text { Stratejik ve Resmi Rasyonel- } \\
\text { lik/Siyasi, Ekonomik, } \\
\text { Örgütsel }\end{array}$ \\
\hline Kamu Yararı Anlayışı & Yasa ile tanımlama & çıkarların & $\begin{array}{l}\text { Paylaşılan değerlere } \\
\text { bağlı diyalog sonucu }\end{array}$ \\
\hline Hizmet Alanlar & Hizmet Alanlar & Müşteriler & Vatandaşlar \\
\hline $\begin{array}{l}\text { Kamu } \\
\text { Kurumlarının Rolü }\end{array}$ & Kürek Çeken & Dümen tutan & Hizmet eden \\
\hline $\begin{array}{l}\text { Amaçlara Ulaşma } \\
\text { Mekanizmaları }\end{array}$ & Kamu Kurumları & $\begin{array}{l}\text { Özel ve Gönüllü Kuru- } \\
\text { luşlar }\end{array}$ & $\begin{array}{l}\text { Kamu, Özel, } \\
\text { Gönüllü Kuruluşlar }\end{array}$ \\
\hline Hesap Verebilirlik & $\begin{array}{l}\text { Hiyerarşik } \\
\text { (Bürokrat/Siyasi) }\end{array}$ & $\begin{array}{l}\text { Pazar Odaklı } \\
\text { (Müşteriler) }\end{array}$ & $\begin{array}{l}\text { Çok yönlü } \\
\text { (Hukuk, topluluk değerleri, } \\
\text { politik normlar) }\end{array}$ \\
\hline İnisiyatif Alma & Sinirlı & Geniş Takdir & $\begin{array}{l}\text { İhtiyaç Duyulduğunda, } \\
\text { Sınırlı }\end{array}$ \\
\hline Örgüt yapısı & $\begin{array}{l}\text { Hiyerarşik/ } \\
\text { Bürokratik }\end{array}$ & Desantralize & Yönetişimsel \\
\hline $\begin{array}{l}\text { Kamu Görevlilerinin } \\
\text { Motivasyon Unsurları }\end{array}$ & $\begin{array}{l}\text { Ücret, sosyal haklar, } \\
\text { kamu hizmeti } \\
\text { ayricalıkları }\end{array}$ & $\begin{array}{l}\text { Girişimcilik ruhu, } \\
\text { devleti küçültmek }\end{array}$ & Kamu hizmeti, kamu değeri \\
\hline
\end{tabular}

Kaynak: (Denhardt ve Denhardt, 2007, s.29'dan uyarlanmıştır).

Kamu yönetimindeki değişim ve dönüşümler kamu hizmeti anlayışını da değiştirmiştir. Demokrasi kuramı etkisinde bilgiye eleştirel bir şekilde bakan yeni yönetim yaklaşımında kamu yararı, toplum tarafından paylaşılan değerler çerçevesinde ortaya çıkan ortak çıkarlar olarak tanımlanmaktadır. Bu ortak çıkarlar kamu kurumları tarafından tespit edilmekte ve bunlara uygun kamu hizmetleri oluşturulmaktadır. Yeni anlayışta kamu görevli- 
lerinin en önemli motivasyon kaynağ 1 kamuya en iyi şekilde hizmet etmektir. Kamuya en iyi şekilde hizmet etmek ise ancak kamu hizmetlerinin müşterileri olan vatandaşların memnuniyet düzeylerini yükseltmekle sağlanabilir (Denhardt ve Denhardt, 2007, s.29).

Yapılan araştırmalar, kamu hizmetlerinin kalitesi ile müşteri memnuniyeti arasında doğrudan bir ilişki bulunduğunu ortaya koymaktadır. Bu bağlamda, vatandaşların memnuniyet düzeylerinin artırılması hizmet kalitesinin yükseltilmesi ile mümkün olmaktadır (Cronin ve diğerleri, 2000, s.193).

Halka en yakın hizmet birimleri olan yerel yönetimler de yerel ölçekteki kamu hizmetlerinin nitelikli bir şekilde sunulmasından sorumludur. Yerel yönetimlerin varlık nedeni, demokrasinin temel aracı olan seçimler vasıtasyyla iradelerini açıklayan seçmenlerdir. Bu nedenle yerel yönetimler her zaman hizmet ettikleri halkla iç içe olmalı ve etkin hizmet üretmelidir. Zira yerel yönetimlerin karar organlarının bir sonraki seçimlerde tekrar iş başına gelmesi ancak etkili ve verimli hizmet üretilmesi ile mümkün olabilmektedir (Özer, 2013, s.19).

Yeni paradigmaların vatandaşları müşteri olarak tanımlaması eleştirilirken; onların talep, beklenti ve memnuniyetlerini yönetimin temeline yerleştirmesi olumlu karşılanmaktadır. Memnuniyet düzeylerinin belirlenmesine yönelik araştırmalar, kamu yönetimindeki ve yönetim-vatandaş ilişkisindeki değişim ve dönüşümleri yansıtması açısından önemlidir. Bu araştırmalar kamu kurum ve kuruluşlarının hizmet kalitesi düzeylerini görebilmeleri açısından da etkilidir. Bu nedenlerle, uzun bir süredir özellikle yerel yönetimlerin sundukları hizmetlere yönelik memnuniyet araştırmaları yapılagelmektedir. Şüphesiz bu araştırmalar yerel yönetimlerin hizmet kalitelerinin dolayısıyla da vatandaşların memnuniyet düzeylerinin yükseltilmesinde olumlu etki yaratmaktadır (Akyıldız, 2012, s.4417). Bu bağlamda memnuniyet araştırmaları hem yerel yöneticiler hem de alanda çalışan bilim insanları için önem arz etmektedir (Van Ryzin, 2004, s.9).

\section{Literatür İncelemesi}

Literatürde vatandaşların kamu hizmetlerinden memnuniyet düzeylerinin belirlenmesine yönelik olarak birçok araştırmanın yapıldığı görülmektedir. Bu çalışmalarda genellikle katılımcıların kamu hizmetlerinden tatmin düzeylerinin ölçülmesi, kamu hizmetleri ile vatandaşların memnuniyet algıları 
arasındaki ilişkinin değerlendirilmesi, kamu hizmetlerinden duyulan memnuniyet düzeyi ile siyasal eğilimler arasındaki ilişkinin belirlenmesi, kamu hizmetlerinden memnuniyet oranlarının demografik göstergelere göre analiz edilmesi gibi konuların araştırıldığı görülmektedir. Kamu hizmetlerine yönelik memnuniyet araştırmaları yerel yönetimler alanında da sıklıkla yapılmaktadır.

Örneğin, Dehoog ve arkadaşları (1990, s.807-837), yerel hizmetlerden vatandaşların duyduğu memnuniyet düzeylerinin belirlenmesinde öznel tutumların etkisini ve kentlere özgü etkileri ortadan kaldırmayı amaçlayan bir test geliştirmişlerdir. Bu test aracilığı ile memnuniyet düzeyi üç temel odak noktasında bir karşılaştırma grubu ile birlikte değerlendirilmiştir. Araştırmadan elde edilen sonuçlara göre, yerel hizmetlerden duyulan memnuniyet düzeyinde etkili olan ya da olmayan etkenler belirlenmeye çalışılmıştır.

Gümüşoğlu ve diğerleri (2003) çalışmalarında Muğla ilinde vatandaşların belediye hizmetlerinden memnuniyet düzeylerinin belirlenmesine yönelik bir çalışma yapmışlardır. Çalışmada Servqual Ölçeği ilk defa bir memnuniyet araştırmasında kullanılmıştır. Model çalışma sonrasında gözden geçirilerek anlamlı değişikliklere uğramıştır. Çalışma sonuçlarına göre Muğla Belediyesi'nin sunmuş olduğu hizmetlerden memnuniyet düzeyleri ile ilgili güvenilir ve anlamlı sonuçlar elde edilmiştir. Bu sonuçlara göre memnuniyet düzeyleri belirli hizmet alanlarında farklılıklar göstermiştir.

Bozlağan (2004, s.121-145) çalışmasında İstanbul İstinye'de ikamet eden vatandaşlar içerisinden kent nüfusunu temsil eden bir kütle üzerinde kamu hizmetlerinden duyulan tatmin oranlarının belirlenmesine yönelik bir araştırma yapmıştır. Araştırmanın sonuçları 1999 yılında TESEV tarafından yapılan benzer bir çalışmanın sonuçları ile karşılaştırmalı olarak değerlendirilmiştir. Araştırma sonuçlarına göre, vatandaşların merkezi hükümet tarafından yürütülen hizmetlerden tatmin düzeyleri düşüktür. Muhtarlık tarafından yürütülen hizmetlerden memnuniyet düzeyinin ise nispeten daha yüksek olduğu görülmüştür. Belediyelerin ise halkın tatmin düzeyi bak1mından en başarılı yönetim birimleri olduğu sonucuna varılmıştır.

Van Ryzin (2004, s.9-28) çalışmasında kentsel hizmetlerden vatandaşların duyduğu memnuniyet düzeyini ölçen tekli ve çoklu ölçekleri karşılaştırmıştır. Bu karşılaştırmada kendisinin geliştirdiği bir likert ölçeğini de kullanmiştır. 
Van Ryzin ve diğerleri (2004, s.331-341) çalışmalarında New York'ta 2000 ve 2001 yıllarında yapılan iki telefon anketinden elde edilen verileri kullanmak suretiyle, katılımcıların yerel hizmetlerden memnuniyet düzeylerini Amerikan Müşteri Memnuniyeti Endeksine (ACSI) göre incelemişlerdir. Araştırma sonuçlarına göre yerel hizmetler olan güvenlik, eğitim, ulaşım, yol hizmetleri gibi alanlarda memnuniyet seviyesinin yüksek olduğu görülmüştür. Ayrıca memnuniyet düzeylerinin demografik göstergelere göre değişim gösterdiği belirlenmiştir. Çalışma Amerikan Müşteri Memnuniyet Endeksi'nin performansının değerlendirilmesi açısından da önemlidir.

Göküş ve Alptürker (2011, s.121-133) çalışmalarında Silifke Belediyesi'nin sunduğu yerel hizmetlere yönelik vatandaşların memnuniyet düzeylerini ve memnuniyet düzeylerinin yaşa, cinsiyete, eğitim düzeyine, gelir düzeyine ve ikamet edilen mahalleye göre farklllık gösterip göstermediğini araştırmıştır. Araştırmada memnuniyet düzeylerinin belirlenmesi için frekans dağılımı, farklılıkların tespitinde ise T-testi ve Anova analizi kullanılmıştır. Araştırma sonuçlarına göre, memnuniyet düzeyi ile cinsiyet; memnuniyet düzeyi ile yaş gruplarl; memnuniyet düzeyi ile eğitim düzeyi ve memnuniyet düzeyi ile gelir düzeyi arasında anlamlı bir fark tespit edilememiştir. Ancak ikamet edilen mahalle ile memnuniyet düzeyleri arasında anlamlı bir farklılık bulunmuştur.

İnce ve Şahin, (2011a) çalışmalarında Konya il merkezinde ikamet eden vatandaşların yerel hizmetlerden memnuniyet düzeyleri üzerine bir araştırma yapmışlardır. Sonraki çalışmalarında İnce ve Şahin, 2011b, s.126-175) bu kez Selçuklu Belediyesi'nin sunduğu hizmetlerden vatandaşların memnuniyet düzeylerini araştırmışlardır. Araştırma sonuçlarına göre memnuniyet düzeyinin siyasi eğilimlere göre değişebileceği hipotezi doğrulanmamıştır. Ayrıca belediye çalışanlarının tutumları ile memnuniyet düzeyi arasında pozitif bir ilişki tespit edilmiştir. Öte yandan yaş grupları ve cinsiyet ile memnuniyet düzeyleri arasında anlamlı bir ilişki tespit edilmezken, eğitim düzeyi ile memnuniyet düzeyi arasında anlamlı bir ilişki bulunmuştur.

Akyıldız (2012, s.4415-4436) çalışmasında Uşak Belediyesi'nin sunduğu hizmetlerden vatandaşların memnuniyet düzeylerini ölçmüştür. Çalışmada 384 vatandaşa yönelik anket uygulanmış; vatandaşların yerel hizmetlerden memnuniyet düzeylerinin yaşa, cinsiyete, mesleğe, eğitim düzeyine ve gelir durumuna göre farklılık gösterip göstermediği araştırılmıştır. Vatandaşların memnuniyet düzeylerinin belirlenmesinde frekans dağılımı; farklılıkların 
tespitinde ise Kruskal Wallis ve Mann Whitney U testleri kullanılmıştır. Araştırma sonuçlarına göre yerel hizmetlerden en memnun grup serbest meslek çalışanları, en memnuniyetsiz grup ise öğrenciler olmuştur. Öte yandan vatandaşların memnuniyet düzeyleri cinsiyete göre farklılaşmamıştir.

Aslan ve Uluocak (2012, s.175-201) çalışmalarında Çanakkale'de ikamet eden vatandaşların belediye hizmetlerinden memnuniyet düzeylerini siyasal eğilimleri ile birlikte analiz etmeyi amaçlayan bir araştırma yapmışlardır. Çalışma anket yöntemini kullanan ampirik bir çalışmadır. Araştırma sonuçlarına göre; katılımclarca belediyenin en başarısız bulunduğu alanlar kentsel altyapı, toplu taşıma, yol kaldırım ve kent içi trafik hizmetleri olmuştur.

Menteşe (2013, s.831-862) çalışmasında Tunceli il merkezinde ikamet eden vatandaşlar üzerinde belediye hizmetlerinden memnuniyet düzeylerinin belirlenmesini amaçlayan bir araştırma yapmıştır. Toplam 538 katılımcıya uygulanan anketler neticesinde halkın belediye yönetimine orta düzeyde katıldığı; genel hizmet kalitesinden ise orta düzeyde memnun olduğu görülmüştür.

Sabuncu (2016, s.164-177) çalışmasında Yalova Belediyesi tarafından sunulan hizmetlerden vatandaşların memnuniyet düzeylerinin belirlenmesine yönelik bir araştırma yapmıştır. Bu araştırmanın amaçlarından birisi de demografik özelliklere göre memnuniyet düzeylerinin farklılık arz edip etmediğinin tespit edilmesidir. Araştırma için toplam 402 anket uygulanmış; 10 hizmet alanı likert ölçeği kullanılarak değerlendirilmiştir. Araştırma sonuçlarına göre Yalova halkı belediye hizmetlerinden orta derecede memnundur. Ayrıca memnuniyet düzeylerinin yaş, cinsiyet ve mesleğe göre farklılık arz ettiği tespit edilmiştir.

Topal ve diğerleri (2019, s.5-13) çalışmalarında Kütahya ilinin Simav ilçesinde ikamet eden vatandaşların yerel hizmetlerden memnuniyet düzeylerini araştırmışlardır. Araştırmada 253 vatandaşa yönelik 5 demografik değişkeni ve 25 memnuniyet göstergesini içeren anketler uygulanmıştır. Katılımcların \%66'sı erkek, \%34'ü kadın olup her yaş ve eğitim seviyesinden katılım sağlanmıştır. Anket çalışmasının tutarlığını saptamak için Cronbach Alfa Katsayısı ‘0,892' olarak belirlenmiştir. Araştırma sonuçları kadın ve erkeklerin hizmetlerden memnuniyet algilarının farklı olduğunu göstermiştir. Örneğin; otopark hizmetleri, ilaçlama ve zabıta hizmetlerinden kadınların memnuniyeti erkeklerden yüksek düzeydedir. Yaş sınıflarına göre, 25 
yaş ve altı gençlerin memnuniyet algısı diğer yaş gruplarına göre yüksek çıkmıştır. 50 ve üzeri yaş aralığındaki katılımcıların düşük bir memnuniyet algısı sergiledikleri tespit edilmiştir. Kişilerin çalıştı̆̆1 sektörlere göre 15 memnuniyet göstergesinde farklı algilara sahip oldukları, diğer 10 göstergede ise farklılık göstermediği görülmüştür.

Literatürdeki incelendiğinde, kamu hizmetlerinden memnuniyet araştırmalarının sıklıkla alanda çalışan bilim insanlarının çalışmalarına, istatistik şirketleri tarafindan yapılan araştırmalara ve lisansüstü tezlere konu olduğu görülmüştür. $\mathrm{Bu}$ alanda literatürün zengin olduğunu söylemek mümkündür. Özellikle il ve ilçe belediyelerinde kamu hizmetlerine yönelik memnuniyet araştırmalarına sıklıkla rastlanmaktadır. Ancak literatürde Kars Belediyesi örneğinde yerel hizmetlere yönelik bir memnuniyet araştırmasına rastlanmamıştır. Literatürdeki bu boşluğu doldurmak amaciyla yerel hizmetlere yönelik bir memnuniyet araştırması ilk kez Kars Belediyesi örneğinde gerçekleştirilmesidir. Bu, çalışmanın özgün bir çalışma olduğunu göstermektedir. Ayrıca mevcut çalışmanın 31 Mart 2019 yerel seçimleri öncesinde gerçekleştirilmesi, vatandaşların güncel bakış açılarının tespit edilmesi açısından önemlidir. Bu unsur da çalışmanın özgünlüğüne katkı sağlamaktadır.

\section{Araştıma Yöntemi}

\section{Araştırmanın Amacı ve Türü}

`Vatandaşların Yerel Hizmetlere Yönelik Memnuniyet Algısı Üzerine Bir Araştırma: Kars Belediyesi Örneği' isimli bu çalışma ile Kars İl merkezinde ikamet eden vatandaşların yerel hizmetlerden memnuniyet düzeylerinin belirlenmesi amaçlanmıştır. Bu kapsamda, vatandaşların Kars ilinde faaliyet gösteren kamu kurum ve kuruluşlarına, belediye birimlerine, belediye hizmetlerine yönelik memnuniyet düzeyleri ile belediye personeline ve yerel sorunlara yönelik algıları belirlenmeye çalışılmıştır. Bu çalışma, konusu açısından vatandaşların yerel hizmetlerden memnuniyet düzeylerini belirlemeyi amaçlayan bir araştırma niteliğindedir. Verilerin elde edilmesinde birincil kaynak araştırması yapılmıştır. 


\section{Araştırmanın Metodolojisi}

Günümüz kamu yönetimi anlayışı, klasik kamu yönetimi anlayışının çağdaş kamu yönetimi anlayışına evrildiği bir paradigma değişimini ifade etmektedir. Sözü edilen çağdaş kamu yönetimi anlayışının temel felsefesini vatandaşın yönetilen yerine neredeyse müşteri olarak görüldüğü ‘vatandaş odaklı' bir yönetim anlayışı oluşturmaktadır.

Bu dönemde akademik alanda da, bu sürecin ruhuna uygun olarak vatandaş memnuniyet düzeyini belirlemeye yönelik araştırmalar yoğunluk kazanmıştır. Keza vatandaş memnuniyeti araştırmaları, topluma sunulan hizmetlerin hız, kalite ve etkinliğinin ölçülmesi ve yerel yönetimlerin vatandaşın dilek, istek ve beklentilerine uygun yenilikçi çözüm ve projeler üretmesine imkân tanıması bakımından oldukça büyük önem taşımaktadır.

Bu kapsamda, bu çalışmanın amacı Kars Belediyesi örneğinde, vatandaşların belediyecilik hizmetlerinden memnuniyet düzeylerinin belirlenmesidir. Çalışmanın evrenini Kars ilinde yaşayanlar oluşturmaktadır. Örneklem ise Kars ilinde yaşayanlar içerisinden Kars kent merkezinde yaşayanlardan oluşmaktadır. Araştırmaya konu belediye hizmetlerinin, belediye mücavir alanı içerisinde sunuluyor olması Kars kent merkezinin araştırma örneklemi olarak seçilmesinde etkili olmuştur. Araştırma kapsamında Kars ilinin seçilmesinin sebebi köklü bir belediyecilik geçmişi olan kentte benzeri bir çalışmanın daha önce yapılmamış olmasıdır.

Araştırmada nicel (kantitatif) araştırma yöntemi kullanılmıştır. Nicel araştırmalar, bir evren içerisinden seçilen örneklem üzerinde gerçekleştirilen çalışmalara dayanır. Örneklem, evren genelindeki tutum, eğilim ve düşüncelerin nümerik olarak betimlenmesine yardımcı olur. Nicel araştırmalarda örneklemden elde edilen veriler kullanarak evren genelinde çıarımlar yapılır. Burada önemli olan sonuç üzerinde etkili olabilecek tüm dişsal faktörlerin kontrol edilmesi ve sonuç üzerindeki etkisinin test edilmesidir. Sözü edilen dışsal faktörleri kontrol etmenin önemli bir yolu katılımciların tesadüfi gruplara atanmasıdır (Creswell, 2016, s.155-156).

Çalışmada örnekleme yöntemi olarak basit tesadüfi örnekleme kullanılmıştır. Bu yöntemde listelenen birimler arasından rastgele seçim yapılmaktadır. Evrenin çok büyük ve karmaşık olmaması durumunda seçim işlemi kolaylaşmaktadır. Ayrıca basit tesadüfi istatistiksel işlemler ağırlıksız olarak 
yapıldığı için değerlendirme ve örnekleme hatası da kolaylıkla hesaplanabilmektedir (Kılıç, 2013, s. 45).

Yukarıdaki açıklamalar çerçevesinde, Kars il merkezinde ikamet eden ve basit tesadüfi örnekleme göre seçilen 550 vatandaşa yönelik olarak uygulanan anketler neticesinde, sorulara titizlikle yanit veren 305 katılımcilının anket formu değerlendirmeye alınmıştır. Uygulanan anket formu; İnce ve Şahin (2011a) tarafindan yapılan araştırmada kullanılan sorulardan uyarlanarak geliştirilmiştir. Anket formunda demografik yapı, kamu kurumlarına yönelik algı ve güven düzeyi, belediye yönetimine ve çalışanlarına yönelik güven düzeyi, belediye hizmetlerinde karşılaşılan sorunlar ve vatandaşların bu hizmetlerden memnuniyet düzeyleri gibi konu başlıklarına kaynak teşkil edecek sorulara yer verilmiştir. Anketlerden elde edilen veriler SPSS 12,0 programı aracilığıyla analiz edilmiş ve yorumlanmıştır.

\section{Analiz ve Bulgular}

Çalışmanın bu bölümünde Kars ilinde ikamet eden katılımcllara ait demografik özellikler, vatandaşların kamu kurum ve kuruluşlarına, belediye birimlerine, belediye personeline ve yerel hizmetlere yönelik algıları ve memnuniyet seviyelerine yönelik bulgular analiz edilmektedir. Bulgular öncelikli olarak tablolarla gösterilmiş daha sonra tablolara ilişkin değerlendirmeler yapılmıştır.

Katılımcların cinsiyet dağılımı incelendiğinde, \%43,1'inin kadın \% 56,9'unun erkek olduğu görülmektedir. Katılımcların cinsiyetlerine göre dağılım oranları 2018 yılı Adrese Dayalı Nüfus Kayıt Sistemi verileri ile büyük oranda benzerlik göstermekte; bu bağlamda evren için iyi bir örneklem oluşturulduğu görülmektedir.

Katılımcıların yaş dağılımları incelendiğinde, örneklemin genç oranı yüksek bir profile sahip olduğu görülmektedir. Şöyle ki; katılımcıların \%52;1'i 18-29 yaş arası; \%33'ü 30-43 yaş arası; \%10,9'u 44-55 yaş arası ve \%4'ü 56 yaş ve üstü yaş aralığındadır. 
Tablo 2. Katılımcılarn Demografik Özellikleri

\begin{tabular}{|c|c|c|c|}
\hline & & Frekans & Yüzde \\
\hline \multirow{3}{*}{ Cinsiyet } & Kadın & 131 & 43,1 \\
\hline & Erkek & 173 & 56,9 \\
\hline & Toplam & 304 & 100,0 \\
\hline \multirow{5}{*}{ Yaş } & $18-29$ yaş & 158 & 52,1 \\
\hline & $30-43$ yaş & 100 & 33,0 \\
\hline & $44-55$ yaş & 33 & 10,9 \\
\hline & 56 ve üstü & 12 & 4,0 \\
\hline & Toplam & 303 & 100,0 \\
\hline \multirow{7}{*}{ Öğrenim } & Okuma Yazma Bilmeyen & 4 & 1,3 \\
\hline & Okur-yazar & 16 & 5,3 \\
\hline & ïlkokul & 33 & 10,9 \\
\hline & Ortaokul & 29 & 9,5 \\
\hline & Lise & 86 & 28,3 \\
\hline & Üniversite ve Üstü & 136 & 44,7 \\
\hline & Toplam & 304 & 100,0 \\
\hline \multirow{4}{*}{ Meslek } & Kamu & 92 & 37,1 \\
\hline & Özel & 100 & 40,3 \\
\hline & Serbest Meslek-Esnaf & 56 & 22,6 \\
\hline & Toplam & 248 & 100,0 \\
\hline \multirow{5}{*}{ Gelir } & $100-500 \mathrm{TL}$ & 28 & 10,7 \\
\hline & 501-1000 TL & 26 & 10,0 \\
\hline & $1001-3000 \mathrm{TL}$ & 128 & 49,0 \\
\hline & 3001 TL ve üstü & 79 & 30,3 \\
\hline & Toplam & 261 & 100,0 \\
\hline \multirow{15}{*}{ Meslek } & Memur & 44 & 14,5 \\
\hline & Kamu Yöneticisi & 4 & 1,3 \\
\hline & Özel & 12 & 3,9 \\
\hline & Kamu İşçisi & 18 & 5,9 \\
\hline & Özel Sektörde İşçi & 39 & 12,8 \\
\hline & İşsiz & 16 & 5,3 \\
\hline & Emekli & 4 & 1,3 \\
\hline & Ev Hanımı & 26 & 8,6 \\
\hline & Öğrenci & 41 & 13,5 \\
\hline & Öğretmen & 32 & 10,5 \\
\hline & Çiftçi & 11 & 3,6 \\
\hline & Esnaf-Tüccar & 38 & 12,5 \\
\hline & Avukat-Doktor-Mühendis & 6 & 2,0 \\
\hline & Diğer & 13 & 4,3 \\
\hline & Toplam & 304 & 100,0 \\
\hline \multirow{3}{*}{ Karslı misınız? } & Evet & 221 & 72,7 \\
\hline & Hayır & 83 & 27,3 \\
\hline & Toplam & 304 & 100,0 \\
\hline \multirow{6}{*}{$\begin{array}{l}\text { Kendinizi Karslı } \\
\text { Hissediyor musunuz? }\end{array}$} & Evet & 195 & 64,1 \\
\hline & Hayır & 83 & 27,3 \\
\hline & Fikrim yok & 26 & 8,6 \\
\hline & Toplam & 304 & 100,0 \\
\hline & $1 \mathrm{yll}$ & 12 & 3,9 \\
\hline & $2 \mathrm{yll}$ & 11 & 3,6 \\
\hline
\end{tabular}




\begin{tabular}{|c|c|c|c|}
\hline \multirow{4}{*}{ İkamet Süresi } & 3 yil & 20 & 6,6 \\
\hline & $4 \mathrm{y} 1 \mathrm{l}$ & 31 & 10,2 \\
\hline & 5 yıl ve üstü & 230 & 75,7 \\
\hline & Toplam & 304 & 100,0 \\
\hline \multirow{23}{*}{ Mahalle } & 30 Ekim Mah. & 10 & 3,8 \\
\hline & Alparslan & 8 & 3,1 \\
\hline & Atatürk & 2 & 0,8 \\
\hline & Aydınlık Evler & 5 & 1,9 \\
\hline & Bahçelievler & 7 & 2,7 \\
\hline & Bayrampaşa & 4 & 1,5 \\
\hline & Bülbül & 6 & 2,3 \\
\hline & Cumhuriyet & 27 & 10,3 \\
\hline & Fevzi Çakmak & 3 & 1,1 \\
\hline & Hafiz Paşa & 5 & 1,9 \\
\hline & Halit Paşa & 10 & 3,8 \\
\hline & İstasyon & 44 & 16,8 \\
\hline & Kaleiçi & 3 & 1,1 \\
\hline & Merkez & 17 & 6,5 \\
\hline & Ortakapı & 30 & 11,5 \\
\hline & Örnek & 2 & 0,8 \\
\hline & Paşaçayır & 3 & 1,1 \\
\hline & Sukapı & 3 & 1,1 \\
\hline & Şehitler & 35 & 13,4 \\
\hline & Yenimahalle & 8 & 3,1 \\
\hline & Yenişehir & 18 & 6,9 \\
\hline & Yusuf Paşa & 12 & 4,6 \\
\hline & Toplam & 262 & 100,0 \\
\hline
\end{tabular}

Öğrenim durumuna göre; katılımcların \%5,3’ü sadece okur-yazar; $\% 10,9^{\prime}$ u ilkokul; \%9,5'i ortaokul; \%28,3'ü lise; \%44,7'si ise üniversite mezunu ve üstü seviyededir. Buna göre örneklemin eğitim seviyesi yüksek bir profili temsil ettiği söylenebilir. Meslek gruplarına göre bir değerlendirme yapmak gerekir ise toplumdaki hemen her meslek grubundan katılımclar olduğu söylenebilir.

Gelir durumu yönünden; katılımcıların \%20,7'si 1000 TL ve altı; \%49'u 1000-3000 TL aras1; \%30,3'ü ise 3000 TL ve üstü gelire sahiptir.

Memleketiniz neresidir? sorusuna verilen yanıtlara göre; katılımciların \% 72,7'si 'Karslı olduğunu', \% 27,3'ü ise 'Karslı olmadığını' beyan etmiştir. 'Kendisini Karslı hissedenlerin' oranı ise \%64,1'dir. Buna göre 'Karslı olduğunu beyan edenler' ile 'kendisini Karslı hissedenler' arasında anlamlı bir farklılık bulunmaktadır. Katılımcıların ikamet ettikleri mahallelere göre dağılımı incelendiğinde, il merkezindeki bütün mahallelerden katılımclar olduğu görülmektedir. 
Tablo 3. Yakın zamanda aşağıdaki kurumlara hiç işiniz düştü mü?

\begin{tabular}{llllll}
\hline & Evet & Yüzde & Hayır & Yüzde & Yüzde \\
\hline Hastane & 209 & 69,7 & 91 & 30,3 & 100,0 \\
\hline Eğitim Kurumları & 162 & 54,0 & 138 & 46,0 & 100,0 \\
\hline Belediye & 104 & 34,6 & 197 & 65,4 & 100,0 \\
\hline Maliye & 84 & 28,0 & 216 & 72,0 & 100,0 \\
\hline Valilik & 75 & 25,0 & 225 & 75,0 & 100,0 \\
\hline Vergi Dairesi & 73 & 24,3 & 227 & 75,7 & 100,0 \\
\hline Emniyet Teşkilatı & 64 & 21,4 & 234 & 78,3 & 100,0 \\
\hline Adliye & 52 & 17,3 & 248 & 82,7 & 100,0 \\
\hline Tapu Daireleri & 38 & 12,7 & 262 & 85,9 & 100,0 \\
\hline STK'lar & 34 & 11,3 & 266 & 88,7 & 100,0 \\
\hline Askeri Kurumlar & 32 & 10,7 & 267 & 89,3 & 100,0 \\
\hline Gümrük & 24 & 8,1 & 274 & 91,9 & 100,0 \\
\hline
\end{tabular}

Tablo 3'te vatandaşların en çok hizmet aldıkları kamu kurum ve kuruluşlar (yüksekten düşüğe doğru) gösterilmiştir. Buna göre, hastaneler \%69,7; eğitim kurumları \%54 ve belediye \% 34,6'lık oranlarla vatandaşlar tarafından en çok hizmet alınan üç kurum olarak sıralanmaktadır. STK'lar \%11,3; askeri kurumlar \%10,7 ve gümrük kurumları \% 8,1 ile en az hizmet alınan kurumlar olarak görülmektedir.

Tablo 4. Kars'taki Kamu Kurum ve Kuruluşlarna Ait Memnuniyet Oranlar

\begin{tabular}{lllllll}
\hline$\%$ & $\begin{array}{l}\text { Hiç memnun } \\
\text { değil }\end{array}$ & $\begin{array}{l}\text { Memnun } \\
\text { değil }\end{array}$ & $\begin{array}{l}\text { Kismen } \\
\text { memnun }\end{array}$ & Memnun & $\begin{array}{l}\text { Çok } \\
\text { memnun }\end{array}$ & Toplam \\
\hline Askeri Kurumlar & 13,3 & 5,4 & 27,8 & 30,3 & 23,2 & 100,0 \\
Emniyet Teşkilatı & 14,1 & 8,6 & 25,4 & 30,9 & 21,1 & 100,0 \\
Maliye & 17,0 & 10,0 & 36,9 & 26,1 & 10,0 & 100,0 \\
Gümrük & 17,4 & 10,9 & 37,8 & 26,1 & 7,8 & 100,0 \\
Valilik & 19,9 & 8,6 & 29,3 & 27,3 & 14,8 & 100,0 \\
Vergi Daireleri & 17,5 & 11,3 & 39,6 & 24,6 & 7,1 & 100,0 \\
Tapu Dairesi & 20,7 & 12,2 & 40,9 & 18,1 & 8,0 & 100,0 \\
STK'lar & 19,6 & 14,2 & 35,0 & 21,3 & 10,0 & 100,0 \\
Eğitim Kurumları & 22,0 & 13,1 & 34,3 & 21,6 & 9,0 & 100,0 \\
Hastane & 34,1 & 15,4 & 28,3 & 15,4 & 6,8 & 100,0 \\
Belediye & 42,3 & 19,1 & 23,2 & 11,0 & 4,4 & 100,0 \\
\hline
\end{tabular}

Tablo 4'te Kars ilindeki kamu kurum ve kuruluşlarına ait memnuniyet oranları gösterilmektedir. Sıralama 'kısmen memnun' 'memnun' ve 'çok memnun' sütunlarının toplamından elde edilen oranlara göre yüksekten düşüğe doğru yapılmıştır. Buna göre, askeri kurumlar \%81,3; Emniyet Teşkilatı \%77,4; Maliye \%73; Gümrük \%71,7 ve Valilik \%71,4'lük oranlarla en 
fazla memnuniyet duyulan kurumlardır. Vergi dairesi \%71,3; tapu dairesi \% 67; eğitim kurumları $\% 64,9$ ve hastaneler $\% 50,5$ ile bu kurumları takip etmektedir. Belediye ise tüm kurum ve kuruluşlar içerisinde $\% 38,6^{\prime} l 1 k$ oranla son sırada yer almıştır.

Tablo 5. Belediye Başkanına Yönelik Sorular

\begin{tabular}{|c|c|c|c|}
\hline & & Frekans & Yüzde \\
\hline \multirow[b]{2}{*}{ Belediye başkanının ismini biliyor musunuz? } & Evet & 230 & 75,9 \\
\hline & Hayır & 73 & 24,1 \\
\hline \multirow[b]{2}{*}{ Belediye başkanını görseniz tanır mısınız? } & Evet & 198 & 65,3 \\
\hline & Hayır & 105 & 34,7 \\
\hline \multirow{3}{*}{ Sizce belediye başkanı belediyeyi iyi yönetiyor mu? } & Evet & 36 & 11,9 \\
\hline & Hayır & 215 & 71,0 \\
\hline & Fikrim Yok & 52 & 17,2 \\
\hline \multirow{5}{*}{ Belediye başkanından memnun musunuz? } & Hiç memnun değil & 86 & 31,2 \\
\hline & Memnun değil & 44 & 15,9 \\
\hline & Kismen memnun & 101 & 36,6 \\
\hline & Memnun & 35 & 12,7 \\
\hline & Çok memnun & 10 & 3,6 \\
\hline
\end{tabular}

Tablo 5'te belediye başkanına yönelik sorulara verilen yanıtlar gösterilmektedir. Buna göre; vatandaşların \%75,9 gibi büyük bir kesimi belediye başkanını ismen tanımaktadır. Belediye başkanını görse tanıyacağını beyan edenlerin oranı ise \%65,3 gibi yüksek bir orandır. Öte yandan, belediye başkanından kısmen de olsa memnun olanların oranı \%52,9; memnun olmayanların oranı ise $\% 47,1^{\prime}$ dir.

Tablo 6. Vatandaşlarn Belediye Başkan İle İlgili Düşünceleri

\begin{tabular}{lllllll}
\hline$\%$ & $\begin{array}{l}\text { Kesinlikle } \\
\text { katılmıyor }\end{array}$ & Katılmıyor & $\begin{array}{l}\text { Kismen } \\
\text { katılıor }\end{array}$ & Katılıyor & $\begin{array}{l}\text { Kesinlikle } \\
\text { Katilıyor }\end{array}$ & Toplam \\
\hline Alanında uzman & 40,0 & 23,1 & 26,6 & 6,9 & 3,4 & 100,0 \\
\hline Çalışkan dinamik & 33,5 & 27,1 & 28,2 & 8,5 & 2,8 & 100,0 \\
\hline Objektif & 32,2 & 27,9 & 28,6 & 7,1 & 4,2 & 100,0 \\
\hline Sorunları çözer & 35,7 & 27,3 & 27,6 & 6,3 & 3,1 & 100,0 \\
\hline Halkla iç içe & 34,3 & 27,3 & 27,6 & 6,6 & 4,2 & 100,0 \\
\hline Vizyon sahibi & 35,7 & 27,6 & 25,1 & 7,4 & 4,2 & 100,0 \\
\hline Güler yüzlü & 28,7 & 18,2 & 31,5 & 12,9 & 8,7 & 100,0 \\
\hline
\end{tabular}

Tablo 6'da vatandaşların belediye başkanı ile ilgili düşünceleri yer almaktadır. Buna göre; kısmen katılanlar dâhil vatandaşların \%36,9'u belediye başkanını alanında uzman; \%39,4'ü çalışkan ve dinamik; \%39,9'u objek- 
tif; \% 37'si yerel sorunlara hakim; \% 38,4'ü halkla iç içe; \%36,7'si vizyon sahibi ve \% 53,1'i güler yüzlü olarak nitelendirmektedir.

Tablo 7. Belediye Çalışanlarına ve Hizmet Birimlerine Yönelik Düşünceler

\begin{tabular}{llll}
\hline & & $f$ & $\%$ \\
\hline \multirow{4}{*}{$\begin{array}{l}\text { Belediye çalışanlarından } \\
\text { memnun musunuz? }\end{array}$} & Hiç memnun değil & 88 & 31,7 \\
\cline { 2 - 4 } & Memnun değil & 58 & 20,9 \\
\cline { 2 - 4 } & Kismen memnun & 91 & 32,7 \\
\cline { 2 - 4 } & Memnun & 33 & 11,9 \\
\cline { 2 - 4 } & Çok memnun & 8 & 2,9 \\
\hline \multirow{3}{*}{$\begin{array}{l}\text { Belediyenin hizmet } \\
\text { birimlerinden } \\
\text { memnun musunuz? }\end{array}$} & Hiç memnun değil & 89 & 32,5 \\
\hline & Memnun değil & 51 & 18,6 \\
\cline { 2 - 4 } & Kismen memnun & 93 & 33,9 \\
\cline { 2 - 4 } & Memnun & 34 & 12,4 \\
\cline { 2 - 4 } & Çok memnun & 7 & 2,6 \\
\hline \multirow{3}{*}{$\begin{array}{l}\text { Belediyeye işiniz düştüğünde } \\
\text { işinizi nasıl hallediyorsunuz? }\end{array}$} & Herhangi bir şey yapmaya gerek duymuyorum & 169 & 57,1 \\
\cline { 2 - 4 } & Tanıdık birilerini buluyorum & 41 & 13,9 \\
\cline { 2 - 4 } & İlgili birimdeki tanıdılarımla hallediyorum & 7 & 2,4 \\
\cline { 2 - 4 } & Fikrim yok & 16 & 21,3 \\
\cline { 2 - 4 } & Diğer & 5,4 \\
\hline
\end{tabular}

Tablo 7'de belediye çalışanlarına ve belediyenin hizmet birimlerine yönelik vatandaş görüsşleri yer almaktadır. Buna göre, kısmen memnuniyet oranı da dâhil olmak üzere vatandaşların belediye çalışanlarından memnuniyet oranı \%47,5 iken belediyenin hizmet birimlerinden memnuniyet oranı $\% 48,9^{\prime}$ dur. Belediyeye işiniz düştügünnde nasıl hallediyorsunuz? sorusuna yönelik oranlar incelendiğinde; vatandaşların \%57,1'lik kesiminin 'herhangi bir girişimde bulunmadan' cevabını verdikleri görülmektedir. 'Bir tanıdığa ulaşırım' şeklinde beyanda bulunanların oranı ise $\% 16,3$ 'le düşük bir seviyededir.

Tablo 8. Belediye Çalışanlarının Davranışlarından Memnuniyet

\begin{tabular}{llll}
\hline & Evet & Hayır & Toplam \\
\hline Güler yüzlü değiller & 47,3 & 52,7 & 100,0 \\
İletişim eksikliği yaşıyoruz & 41,9 & 58,1 & 100,0 \\
İlgili değiller & 38,9 & 61,1 & 100,0 \\
İşler sistemsiz bir şekilde yürüyor & 31,2 & 68,8 & 100,0 \\
Alan yeterlilikleri zayıf & 30,3 & 69,7 & 100,0 \\
Alternatif çözüm üretmiyorlar & 18,1 & 81,9 & 100,0 \\
\hline
\end{tabular}

Tablo 8'de vatandaşların belediye çalışanlarından memnun olmama nedenleri ve oranları gösterilmektedir. Bu soruda katılımclara birden fazla 
seçeneği işaretleyebilecekleri belirtilmiştir. Buna göre, vatandaşların $\% 47,3^{\prime} \ddot{u}$ çalışanların güler yüzlü olmadığını; $\% 41,9^{\prime}$ u çalışanlarla iletişim sorunları yaşadıklarını; \% 38,9'u çalışanların sorunlarla ilgili olmadığını; \% 31,2'si işlerin sistemsiz bir şekilde yürüdüğünü; \% 30,3'ü çalışanların yerel hizmetlerle ilgili yeterliliklerinin olmadığını; \%18,1'i çalışanların alternatif çözüm üretmediklerini ifade etmiştir.

Tablo 9. Sizce belediye birimlerinde etkin hizmet sunuluyor mu?

\begin{tabular}{lll}
\hline & $f$ & $\%$ \\
\hline Evet & 33 & 11,2 \\
Hayır & 133 & 45,1 \\
Kismen & 129 & 43,7 \\
\hline
\end{tabular}

Tablo 9'da Belediye birimlerinin hizmet etkinliğine yönelik görüşlere ait oranlar yer almaktadır. Buna göre, katılımciların \%45,1'i etkin hizmet alamadıklarını belirtirken \%11,2'si etkin hizmet aldıklarını beyan etmiştir. Kısmen etkin hizmet sunulduğunu düşünenlerin oranı ise \%43,7' dir.

Tablo10. Eğer etkin hizmet sunulmadığını düşünüyorsanız, bunun sebepleri nelerdir?

\begin{tabular}{llll}
\hline & Evet & Hayır & Toplam \\
\hline Çalışanların tutum ve davranışları & 54,9 & 45,1 & 100,0 \\
\hline Yönetici tutum ve davranışları & 35,0 & 65,0 & 100,0 \\
\hline Görev ve sorumlulukların tanımlanmaması & 34,3 & 65,7 & 100,0 \\
\hline Belediyenin maddi imkânsılıkları & 31,6 & 68,4 & 100,0 \\
\hline Bürokratik işlemlerin fazlalığı & 31,0 & 69,0 & 100,0 \\
\hline Alternatif çözüm üretmeme & 18,5 & 81,5 & 100,0 \\
\hline
\end{tabular}

Katılımcılara 'Belediye birimlerinin etkin olmadığını düşünüyorsanız sebeplerini belirtiniz ?' şeklinde bir soru yöneltilmiş; soruya verilen yanıtların oranları Tablo 10'da gösterilmiştir. Buna göre, katılımcların \%54,9'u etkinsizliğin nedenini çalışanların tutum ve davranışlarına; \%35'i yöneticilerin tutum ve davranışlarına; \%34,3'ü görev ve sorumlulukların yeterince tanımlanmamasına; \%31,6'sı belediyenin maddi imkânsızlıklarına; \%31'i bürokratik işlemlerin fazlalığına ve \%18,5'i alternatif çözüm üretilmemesine bağlamaktadır. 
Tablo 11. Yerel Hizmetlerden Memnuniyet Oranı

\begin{tabular}{|c|c|c|c|c|c|c|}
\hline & $\begin{array}{l}\text { Hiç mem- } \\
\text { nun değil }\end{array}$ & $\begin{array}{l}\text { Memnun } \\
\text { değil }\end{array}$ & $\begin{array}{l}\text { Kismen } \\
\text { memnun }\end{array}$ & Memnun & $\begin{array}{l}\text { Çok } \\
\text { memnun }\end{array}$ & Top. \\
\hline Cadde/sokak temizliği & 51,7 & 21,1 & 20,5 & 4,0 & 2,7 & 100,0 \\
\hline Çevre koruma hizmetleri & 50,7 & 22,1 & 19,7 & 5,4 & 2,0 & 100,0 \\
\hline Yeşil alan/park/ağaçlandırma & 52,0 & 20,5 & 21,1 & 4,4 & 2,0 & 100,0 \\
\hline Otopark hizmetleri & 52,8 & 19,2 & 18,9 & 5,9 & 3,1 & 100,0 \\
\hline Yol yapım/bakım & 53,3 & 17,2 & 22,0 & 4,5 & 3,1 & 100,0 \\
\hline İmar hizmetleri & 51,5 & 18,8 & 22,2 & 5,8 & 1,7 & 100,0 \\
\hline $\begin{array}{l}\text { Sosyal tesislerin inşası ve } \\
\text { bakımı }\end{array}$ & 48,6 & 21,2 & 21,2 & 5,8 & 3,1 & 100,0 \\
\hline Fiziki mekân/tarihi doku & 50,3 & 18,5 & 22,6 & 6,2 & 2,4 & 100,0 \\
\hline Atık su aritma & 48,3 & 20,0 & 23,8 & 4,8 & 3,1 & 100,0 \\
\hline İçme suyu hizmetleri & 49,3 & 18,0 & 23,8 & 5,4 & 3,4 & 100,0 \\
\hline Katı atık/çöp toplama & 48,1 & 18,6 & 25,4 & 4,8 & 3,1 & 100,0 \\
\hline Haşere ile mücadele & 46,9 & 18,5 & 25,3 & 4,8 & 4,5 & 100,0 \\
\hline Fiyat kontrolü & 46,3 & 18,9 & 27,0 & 4,7 & 3,0 & 100,0 \\
\hline Kanalizasyon hizmetleri & 47,6 & 16,9 & 24,8 & 6,9 & 3,4 & 100,0 \\
\hline Ulaşım hizmetleri & 50,5 & 13,7 & 23,0 & 7,9 & 4,8 & 100,0 \\
\hline Zabita hizmetleri & 47,4 & 15,9 & 26,6 & 6,2 & 3,8 & 100,0 \\
\hline Sosyal yardım hizmetleri & 39,9 & 22,9 & 28,8 & 4,5 & 3,8 & 100,0 \\
\hline Trafik hizmetleri & 46,1 & 16,4 & 25,7 & 7,5 & 4,3 & 100,0 \\
\hline Yap1 denetimi & 44,1 & 17,7 & 30,9 & 4,2 & 3,1 & 100,0 \\
\hline Kültür/sanat hizmetleri & 40,7 & 18,3 & 26,4 & 9,2 & 5,1 & 100,0 \\
\hline Cadde/sokak aydınlatma & 43,4 & 15,2 & 26,6 & 9,7 & 5,2 & 100,0 \\
\hline $\begin{array}{l}\text { Mezbaha/veterinerlik } \\
\text { hizmetleri }\end{array}$ & 39,3 & 18,6 & 29,3 & 9,7 & 3,1 & 100,0 \\
\hline Halk sağlığı denetimleri & 39,4 & 17,8 & 29,6 & 8,8 & 4,4 & 100,0 \\
\hline Sağlık hizmetleri & 39,9 & 16,9 & 29,4 & 10,1 & 3,7 & 100,0 \\
\hline Mezarlık hizmetleri & 34,6 & 16,1 & 30,0 & 13,9 & 5,4 & 100,0 \\
\hline İtfaiye/ambulans hizmetleri & 31,1 & 14,2 & 29,4 & 17,0 & 8,3 & 100,0 \\
\hline
\end{tabular}

Tablo 11'de katılımcıların yerel hizmetlerden memnuniyet oranları gösterilmiştir. Buna göre; katılımcıların \%72,8'i cadde ve sokakların temizliğinden; $\% 72,8$ 'i çevre koruma hizmetlerinden; $\% 72,5$ 'i yeşil alan/park ve ağaçlandırma hizmetlerinden; \%72'si otopark hizmetlerinden; \%70,5'i yol yapım ve bakım hizmetlerinden, $\% 70,3$ 'ü imar hizmetlerinden; $\% 69,8$ 'i sosyal tesislerin inşası ve bakımından; \%68,8'i fiziki mekân düzenlemesi ve tarihi doku koruma hizmetlerinden $\% 68,3$ '̈u atık su hizmetlerinden; \%67,3'ü içme suyu hizmetlerinden; \%66,7'si katı atık ve çöp toplama hizmetlerinden; \%65,4'ü haşere ile mücadele hizmetlerinden; \%65,2'si fiyat kontrol hizmetlerinden; \% 64,5 kanalizasyon hizmetlerinden memnun olmadıklarını beyan etmişlerdir. Katılımcların en az memnuniyetsizlik gösterdiği hizmetler ise 
$\% 45,3$ 'lük oranla itfaiye/ambulans hizmetleri; \%50,7 ile mezarlık hizmetleri ve $\% 56,8^{\prime}$ lik oranla sağlık hizmetleridir.

Tablo 12. Sizce Kars'ta çözülmesi gereken en önemli yerel sorun nedir?

\begin{tabular}{llll}
\hline & Evet & Hayır & Toplam \\
\hline Çöp/Cadde ve Sokak temizliği & 78,8 & 21,4 & 100,0 \\
\hline Yol yapımı ve onarımı & 66,1 & 33,9 & 100,0 \\
\hline Sosyal Alan/Sosyal Faaliyet & 48,5 & 51,6 & 100,0 \\
\hline Alt yapı/Kanalizasyon & 47,7 & 52,3 & 100,0 \\
\hline Yeşil Alan/Park Oyun Alanı & 47,4 & 52,6 & 100,0 \\
\hline Yoksulluk/İssizlik/İstihdam & 44,4 & 55,6 & 100,0 \\
\hline Ulaşım & 41,1 & 58,9 & 100,0 \\
\hline İçme Suyu Temizliği & 38,2 & 61,6 & 100,0 \\
\hline Cadde sokak/Kaldırım & 37,5 & 62,5 & 100,0 \\
\hline Doğa ve Tarihi Dokunun Korunması & 33 & 67 & 100,0 \\
\hline Otopark & 26,3 & 73,7 & 100,0 \\
\hline Halk Sağlı̆̆ı/Güvenliği & 21,4 & 78,6 & 100,0 \\
\hline Trafik & 17,4 & 82,6 & 100,0 \\
\hline İmar & 16,1 & 83,9 & 100,0 \\
\hline Çarpık Kentleşme & 15,8 & 84,2 & 100,0 \\
\hline Sağlik & 15,1 & 84,9 & 100,0 \\
\hline Turizmde Tanitım Eksikliği & 14,1 & 85,9 & 100,0 \\
\hline Işılandırma Eksikliği & 14,1 & 85,9 & 100,0 \\
\hline Elektrik Şebekesi & 11,5 & 88,5 & 100,0 \\
\hline
\end{tabular}

Katılımclara Kars'ta çözülmesi gereken en önemli yerel sorunun ne olduğu sorusu yöneltilmiş, birden fazla seçeneği işaretleyebilecekleri belirtilmiştir. Tablo 12 'de bu soruya verilen yanttlar görülmektedir. Buna göre; katılımcıların \% 78,8'lik büyük bir kısmı cadde ve sokakların temizliğini en önemli yerel sorun olarak değerlendirmiştir. Bunu \%66,1'lik oranla yol yapımı ve onarımı izlemektedir. Katılımcılara göre en önemli üçüncü sorun ise $\% 48,5$ ile yeterli sosyal alanların olmayışıdır. Altyapı/kanalizasyon sorunları $\% 47,7$; yeşil alan/park/oyun alanı eksikliği \%47,4; işsizlik/yoksulluk \%44,4; ulaşım sorunları \%41,1 ile bunu takip etmektedir. Katılımcılara göre turizmde tanıtım eksikliği \%14,1; 1şıklandırma eksikliği \%14,1 ve elektrik şebekesine yönelik sorunlar \%11,5'lik değerlerle önem seviyesi en düşük sorunlardır. 
Tablo 13. Kentin Genel İmajı, Yerel Hizmetlerden ve Yaşam Kalitesinden Memnuniyet Oranlar

\begin{tabular}{llll}
\hline & & \multicolumn{1}{c}{$f$} & $\%$ \\
\hline \multirow{5}{*}{ Kentin Genel İmaji } & Hiç memnun değil & 132 & 44,7 \\
\cline { 2 - 4 } & Memnun değil & 54 & 18,3 \\
\cline { 2 - 4 } & Kismen memnun & 81 & 27,5 \\
\cline { 2 - 4 } & Memnun & 19 & 6,4 \\
\cline { 2 - 4 } Yerel Hizmetlerden (Genel) & Çok memnun & 9 & 3,1 \\
\cline { 2 - 4 } & Hiç memnun değil & 131 & 44,3 \\
\cline { 2 - 4 } & Memnun değil & 52 & 17,6 \\
\cline { 2 - 4 } & Kismen memnun & 87 & 29,4 \\
\cline { 2 - 4 } Kentteki Yaşam Kalitesinden & Çok memnun & 19 & 6,4 \\
\hline & Hiç memnun değil & 141 & 2,4 \\
\cline { 2 - 4 } & Memnun değil & 50 & 16,6 \\
\cline { 2 - 4 } & Kismen memnun & 77 & 26,0 \\
\cline { 2 - 4 } & Memnun & 16 & 5,4 \\
\cline { 2 - 4 } & Çok memnun & 12 & 4,1 \\
\hline
\end{tabular}

Tablo 13 'te kentin genel imajı, yerel hizmetler ve yaşam kalitesinden memnuniyet oranları gösterilmektedir. Buna göre; katılımcların \% 63’ü kentin imajindan; $\% 61,9^{\prime}$ u genel olarak yerel hizmetlerden ve $\% 64,5^{\prime} \mathrm{i}$ kentteki yaşam kalitesinden memnun olmadıklarını beyan etmişlerdir.

\section{Genel Değerlendirme, Sonuç ve Öneriler}

Yerel yönetimler vatandaşlara en yakın hizmet birimleridir. Bu çerçevede yerel yönetimlerden; vatandaşların talep ve beklentilerine yüksek oranda yanit vermeleri, hizmet sunumunda etkin ve verimli olmaları beklenmektedir. Memnuniyet araştırmaları, yerel yönetimlerin kurumsal ve fonksiyonel açlardan vatandaşların beklentilerini ne düzeyde karşıladıklarını göstermeleri açısından önemlidir. Bu nedenle, bu tür araştırmalara literatürde sıklıkla rastlanmaktadır. Bu noktada mevcut araştırmayı diğer araştırmalar ile birlikte mukayeseli olarak değerlendirmek literatüre katkı sağlamak açısından faydalı olabilir. Örneğin, yerel hizmetlerden genel memnuniyet seviyesi açısından çalışmamızın bulguları Menteşe (2013) ve Sabuncu (2016)'nun çalışmalarından elde edilen bazı bulgularla mukayese edilebilir. Sözü edilen çalışmalar, sırasıyla Tunceli ve Yalova Belediyeleri'nce sunulan hizmetlerden vatandaşların genel olarak orta düzeyde memnun oldukların göster- 
miştir. Çalışmamızın bulgularına göre ise Kars Belediyesi tarafından sunulan hizmetlerinden genel memnuniyet düzeyi orta seviyenin altındadır. Öte yandan, çalışmamızın sonuçları çeşitli belediye hizmetlerinde vatandaşların memnuniyet düzeylerinin farklılaştı̆̆ını göstermiştir. Bu açıdan, Gümüşoğlu ve diğerlerinin (2003) Muğla Belediyesi örneğinde gerçekleştirdikleri çalışma ile benzer sonuçlara ulaşıldığı söylenebilir. Araştırmamızda daha önce tartışılan bulgulara yönelik bazı tespitlerde bulunulmuştur. Bu tespitler şu şekilde sıralanabilir:

- Kars ilinde vatandaşların en çok hizmet aldıkları birimlerden bir tanesi belediyedir. Ancak diğer kamu kurum ve kuruluşları içerisinde vatandaşların en az memnuniyet bildirdiği birim de belediye kurumudur. Memnuniyet sıralamasında bir yerel yönetim kuruluşunun merkezi idarenin taşra kurumlarının dahi gerisinde kalması yerel yönetimlerin doğasına aykırıdır. Bu nedenle vatandaşların yönetime katılımı teşvik edilmeli, vatandaş belediye ilişkilerinin geliştirilmesi için gerekli adımlar atılmalıdır.

- Belediyenin yürütme organı ve başı olan belediye başkanı, Karslı vatandaşlar tarafından genel olarak tanınmaktadır. Başkanın tanınır olması olumludur. Ancak vatandaşların neredeyse yarısı belediye başkanlarından memnun olmadığın beyan etmiştir. Belediye başkanının halkla daha yakın ilişkiler geliştirmesi gerektiği düşünülmektedir.

- Katılımciların yarısından fazlası belediye personelinden memnun olmadıklarını beyan etmişlerdir. Katılımcılar, memnuniyetsizlik nedenlerini, çalışanların güler yüzlü olmaması, ilgi ve iletişim eksikliği olarak sıralamaktadır. Öte yandan, katılımcıların büyük kısmı çalışanların tutum ve davranışlarını hizmet etkinliğinin önünde önemli bir engel olarak görmektedir. Bu çerçevede, belediyenin halkla ilişkiler faaliyetlerinin artırılması, mevcut uygulamaların yeniden gözden geçirilmesi gerektiği düşünülmektedir.

- Karslı vatandaşların en az memnuniyet duyduğu yerel hizmetler, cadde ve sokak temizliği, çevre koruma, yeşil alan ve ağaçlandırma hizmetleri, otopark hizmetleri, yol yapım ve onarım hizmetleri ve imar hizmetleridir. Buna karşın en çok memnuniyet duyulan hizmetler, mezbaha ve veterinerlik hizmetleri, halk sağlı̆ı denetimleri, sağlık hizmetleri, mezarlık hizmetleri ve itfaiye/ambulans hizmetleridir. Katılımclar, kentin en önemli sorunlarını çöp toplama hizmetleri, cadde ve 
sokakları temizliği ve sosyal alanların yetersizliği olarak belirtmişlerdir. Buna karşın, kent tanıtımı, 1şıklandırması ve elektrik şebekesi katılımc1larca sorun olarak görülmeyen hizmetlerdir. Karslı vatandaşların büyük çoğunluğu, kentin genel imajından, yerel hizmetlerden ve kentteki yaşam kalitesinden memnuniyetsizlik duymaktadır. Belediyenin araştırmanın sonuçlarına göre yeterince etkin olmayan hizmet alanlarında yeni stratejiler ve projeler geliştirmesi gerektiği düşünülmektedir.

Araştırma kapsamında tespit edilen ve yukarıda sayılan sorunların çözümü için izlenmesi gereken stratejiler ise şöyle sıralanabilir:

- Halk katılımına daha fazla önem verilmesi; vatandaşların kent konseyi, meclis toplantıları vb. uygulamalara katılımının teşvik edilmesi,

- Halkla ilişkilere yönelik faaliyetlerin artırılması, belediye personeline yönelik halkla ilişkiler eğitimleri düzenlenmesi,

- Yerel sorunların tespitinde geniş bir paydaş kitlesine danışılması,

- Vatandaşların memnun olmadığı alanlarda çalışmalarını yoğunlaştırmasi,

- Stratejik planlamaya ve performans değerlendirmesine önem gösterilmesi,

- Faaliyetlerin ve çıtıların denetlenmesi ve kamuoyuna raporlanmas1.

Son olarak yukarıda sayılan çözümünde, belediye ile birlikte diğer kent paydaşları olan merkez teşkilatının taşra kurumları, sivil toplum örgütleri, özel sektör kuruluşları, sanayi kuruluşları, üniversite ve vatandaşlar arasında işbirliği ve iletişimin artırılmasının önem arz ettiği değerlendirilmektedir. 


\title{
EXTENDED ABSTRACT
}

\section{A Research on Citizens' Perceptions of Satisfaction for Local Services: The Case of Kars Municipality}

\author{
$*$ \\ Onur Akçakaya - Zeynep Ceylin Ecer \\ Ardahan University
}

Public administration discipline has been witnessing radical paradigm shifts with the rise of neo-liberalism since the early 1980s. As a result, the classical management approach, which has been the basis of public administration for many years, has been replaced by contemporary approaches. New approaches, which are generally market-based, gathered under the of 'new public management'. New public management characterizes citizens as customers; and adopts a number of market-based principles into the public management. These principles, regarding the main characteristics of public service, can be listed as effectiveness, efficiency, speed, accountability and transparency in public services. The transformations in the understanding of public service also concern local governments, which are the closest service units to the citizens. Citizens' expectations to get effective, fast and quality service increase the pressure on local decision-makers. In addition, winning the local elections depends on a high level of satisfaction with the citizens. In this context, it is significantly important to determine the level of satisfaction of the citizens from the local services. However, despite some exceptions, many local administrators neglect satisfaction surveys towards citizens.

There are many studies in the literature on the evaluation of citizen satisfaction with local services. Despite this, we find a gap in the literature about citizen satisfaction research for local services in the case of Kars Municipality (in Turkey). With this motivation, the aim of present study is to evaluate the satisfaction levels of citizens from municipal services in the case of Kars Municipality. In the study, quantitative research method and face-to-face interview technique are used. In this framework, a total of 550 questionnaires were distributed to the participants, considering the research universe and sample. However, the questionnaires of the participants who meticulo- 
usly answered the questions are evaluated. The universe of the study consists of people living in Kars province in Turkey. The sample consists of people living in the city center of Kars. The data obtained from the questionnaires are analysed and interpreted using the SPSS 12.0 package program. Percentage / frequency distribution tables are used in the analysis of the data.

This study consists of four sections. In the first section, the changes in the concept of public service are examined theoretically within the framework of theoretical and practical transformations in public administration. In the second section of the study, the present literature about citizens' perceptions of satisfaction for local service is reviewed comprehensively. In the third section, the methodology, research design and data collection is outlined. Then, the findings of the study are presented and discussed comprehensively in the fourth section. The concludes and contributions of the paper are discussed in the last section.

According to some of the results of the research, public institutions that citizens are most trusted are military institutions, police and financial institutions. The municipality takes the last place as the least trusted organization. In addition, more than half of the citizens declared that they are not satisfied enough with the mayor and the municipal staff. According to the participants, the municipal staff is not friendly enough and concerned. In addition, the rate of those who state that they have communication problems with municipal employees is high. While the local services that citizen are most satisfied with are public health inspections, cemetery and fire / ambulance services; services with the lowest level of satisfaction; street / street cleaning, environmental protection, afforestation, parking services and road construction and maintenance services. Based on these data and findings, it can be said that; there is a similarity between the satisfaction levels of citizens and the topics they perceive as a problem. Thus, what the participants accepted as a problem such as cleaning of the streets, lack of road construction and maintenance services, and insufficient social facilities are also among the topics that citizens have the lowest level of satisfaction with local services. For the solution of the problems identified within the findings of the research, the main recommendations for decision makers are as follows: increasing participation and public relations activities; attaching importance to strategic planning, performance evaluation and reporting. 


\section{Kaynakça / References}

Akyıldız, F. (2012). Belediye hizmetleri ve vatandaş memnuniyeti:Uşak Belediyesi örneği. Journal of Yasar University, 26(7), 4415-4436.

Aslan, C. ve Uluocak, Ş. (2012). Belediye hizmetlerinden memnuniyet düzeyleri üzerine bir araştırma: Çanakkale örneği. Uluslararası Insan Bilimleri Dergisi, 9(1), 174-201.

Bozlağan, R. (2004). Kentsel kamu hizmetlerinden tatmin düzeyi: İstinye-İstanbul örneği. Kocaeli Üniversitesi Sosyal Bilimler Enstitüsü Dergisi, 7(1), 121-145.

Creswell, J. W. (2016). Araştırma deseni. (S. B. Demir, Ed.) (2. Baskı.). Ankara: Eğiten Kitap.

Cronin, J. J., Brady, M. K. ve Hult, G. T. (2000). Assessing the effects of quality, value, and customer satisfaction on consumer behavioral intentions in service environments. Journal of Retailing, 76(2), 193-218. doi:10.1016/S00224359(00)00028-2

DeHoog, R. H., Lowery, D. ve Lyons, W. E. (1990). Citizen satisfaction with local governance: A test of individual, jurisdictional, and city-specific explanations. Journal of Politics, 52(3), 807-837.

Denhardt, J.V.; Denhardt, R. B. (2007). New public service: Serving, not steering (Expanded E.). New York: M.E.Sharpe.

Denhardt, R.B. (2000). Theories of public organization. Boston: Cengage Wadsworth.

Denhardt, Robert B. ve Denhardt, J. V. (2000). The new public service: Serving rather than steering. Public Administration Review, 60(6), 549-559. doi:10.1111/00333352.00117

Eryılmaz, B. (2010). Kamu yönetimi. Ankara: Okutman Yayıncılık.

Göküş, M. ve Alptürker, H. (2011). Belediyelerin sunduğu hizmetlerde vatandaş memnuniyeti: Silifke Belediyesi örneği. Selçuk Üniversitesi Sosyal Bilimler Enstitüsü Dergisi, 25, 121-133.

Gözler, K. ve Kaplan, G. (2012). Kısa idare hukuku (İkinci Bas.). Bursa: Ekin Basın Yayın Dağıtım.

Gruening, G. (2001). Origin and theoretical basis of New Public Management. International Public Management Journa, 4, 1-25.

Gümüşoğlu, Ş., Erdem, S., Kavrukkoca, G. ve Özdağoğlu, A. (2003). Belediyelerde beklenen algilanan hizmet kalitesinin " SERVQUAL " modeli ile ölçülmesi ve Muğla ilinde bir uygulama. Ulusal Üretim Araştırmalar Sempozyumu içinde.

Hood, C. (1991). A public management for all seasons? Public Administration, 69, 319. 
İnce, M. ve Şahin, K. (2011a). Belediye Hizmetleri ve hizmet kalitesine yönelik vatandaş memnuniyetinin ölçümü: Konya İl Merkezi örneği. Karamanoğlu Mehmetbey Üniversitesi.

İnce, M. ve Şahin, K. (2011b). Belediye hizmetlerinde vatandaş memnuniyeti ölçümü: Selçuklu Belediyesi örneği. Sosyal ve Ekonomik Araştrmalar DergisiSelçuk Üniversitesi, 15(21), 126-175.

Katsamunska, P. (2012). Classical and modern approaches to public administration. Economic Alternatives, (1), 74-81.

Kilıç, S. (2013). Sampling methods. Journal of Mood Disorders, 3(1), 44. doi:10.5455/jmood.20130325011730

Menteşe, S. (2013). Halkın belediye hizmetlerinden memnuniyet düzeyinin Tunceli Belediyesi yönünden değerlendirilmesi. The Journal of Academic Social Science Studies, 6(6), 831-862.

Özer, M. A. (2013). Yerel yönetimlerin varlık nedeni olarak halkla ilişkiler. Kafkas Üniversitesi iktisadi ve İdari Bilimler Dergisi, 4(5), 19-50.

Sabuncu, İ. (2016). Belediye hizmetlerinde vatandaş memnuniyet araştırmass: Yalova örneği. Turkish Journal of Marketing, 1(3), 164-177. doi:10.30685/tujom.v1i3.16

Thorsen, E. D. (2009). The neoliberal challenge. What is neoliberalism? 30.05.2019 tarihinde http://folk.uio.no/daget/neoliberalism2.pdf. adresinden erişildi.

Topal, B., Şahin, H. ve B., T. (2019). Belediye Hizmetlerinden Memnuniyetin Ölçülmesine Yönelik Bir Araşturma: Simav Belediyesi Örneği. Balkan Journal of Social Sciences, 8(15), 5-13.

Van Ryzin, G. G. (2004). The measurement of Overall Citizen Satisfaction. Public Performance E Management Review, 27(3), 9-28.

Van Ryzin, G. G., Muzzio, D., Immerwahr, S., Gulick, L. ve Martinez, E. (2004). Drivers and consequences of citizen satisfaction: An application of the American customer satisfaction index model to New York City. Public Administration Review, 64(3), 331-341. doi:10.1111/j.1540-6210.2004.00377.x

\section{Kaynakça Bilgisi / Citation Information}

Akçakaya, O. ve Ecer, C. Z. (2020). Vatandaşların yerel hizmetlere yönelik memnuniyet algıları üzerine bir araştırma: Kars Belediyesi örneği. OPUS-Uluslararası Toplum Araştırmaları Dergisi, 16(27), 516-543. DOI: $10.26466 /$ opus.676976 